\title{
Habitat Characterization of Mansonia spp as Filariasis Vector in Banyuasin, South Sumatra, Indonesia
}

\author{
Rini Pratiwi ${ }^{1, *}$, Chairil Anwar ${ }^{2 *}$, Salni $^{3}$, Hermansyah $^{4}$, Novrikasari ${ }^{5}$, Rachmat Hidayat $^{6}$

 \\ ${ }^{1}$ Ph.D student, Environmental Science, Universitas Sriwijaya, Palembang, Indonesia \\ ${ }^{2}$ Department of Parasitology, Faculty of Medicine, Universitas Sriwijaya, Palembang, Indonesia \\ ${ }^{3}$ Department of Biology, Faculty of Mathematics and Natural science, Universitas Sriwijaya, \\ Palembang, Indonesia \\ ${ }^{4}$ Department of Chemistry, Faculty of Mathematics and Natural science, Universitas Sriwijaya, \\ Palembang, Indonesia \\ ${ }^{5}$ Department of Public Health, Faculty of Medicine, Universitas Sriwijaya, Palembang, Indonesia \\ ${ }^{6}$ Department of Pharmacology, Faculty of Medicine, Universitas Sriwijaya, Palembang, Indonesia \\ ${ }^{7}$ Department of Parasitology, Faculty of Medicine, Universitas Muhammadiyah Palembang, \\ Palembang, Indonesia \\ chairi153@fk.unsri.ac.id
}

\begin{abstract}
Filariasis is caused by microfilariae parasites transmitted through mosquitoes, one of which is Mansonia spp. Environmental characteristics are crucial component for vector control in handling filariasis because they indicate mosquitoes' range of survival. This study aimed to determine the environmental characteristics in the abundance of Mansonia spp. This study was conducted in two lowland areas located in Sedang and Muara Sugih Village, Indonesia, April 2017-April 2018. Environmental characteristics were determined by thermometers and sling hygrometers, and sampling for physical and chemical properties of water. Sedang Village had larger quantity of Mansonia spp variances compared to Muara Sugih, with 6 species and 5 species found respectively. Muara Sugih was slightly higher in temperature and humidity. Sedang water had higher turbidity, higher temperature, higher $\mathrm{pH}$, lower BOD-COD, lower TDS-TSS, with higher coliform counts. Sedang dominant land utilization was plantations, while Muara Sugih was rice field. The dominant aquatic plant in Sedang was Pistia stratiotes and Muara Sugih was Oryza sativa. Differences in temperature, humidity, water parameters, aquatic plants, and land utilization factors resulted in discrepancy of Mansonia spp abundance.
\end{abstract}

\section{Introduction}

Filariasis has become a significant cause of permanent disability worldwide. Filariasis causes approximately 19.43 million cases of hydrocele, 16.68 million cases of lymphoedema and 2.02 million disabilities [1,2]. Lymphatic filariasis is a tropical disease caused by microfilaria parasites invading the lymphatic system. Filariasis attacks 67.88 million people in 73 countries worldwide [1,3]. Microfilariae parasites are transmitted 
through mosquitoes, one of which is the main genus of Mansonia [4]. Mansonia spp habitat consists of swamps, large rivers at the edge of the forest, or in the areas within the forest. The larvae and pupae are attached to the roots of aquatic plants [5].

Banyuasin is a filariasis endemic region accounted for $82 \%$ cases of chronic filariasis for South Sumatra Province Indonesia, in 2014 [6,7]. Banyuasin has a topography of $80 \%$ flat area in the form of tidal swamp lands. This conditions shapes Banyuasin a suitable area for mosquito breeding. Environmental characteristics such as temperature and humidity indicate the range of living survival for mosquitoes, as well as other factors such as moisture and water parameters. Thus, in vector control of filariasis cases, environmental characterization becomes a crucial component. This study aimed to determine the environmental characteristics in the abundance of mosquito Mansonia spp.

\section{Materials and Methods}

\subsection{Study Area}

This study was conducted in two lowland areas, Sedang Village and Muara Sugih Village, located in Banyuasin Regency, from April 2017 to April 2018. The collection of mosquitoes was done in 24 hours pattern (18 pm, until $17 \mathrm{pm}$ of the next day), with human landing collection technique, performed by 6 people indoor and outdoor using an aspirator. The captured mosquitoes were inserted into paper cup. Identification of mosquito species was done based on Rampa and Wharton book [8,9].

\subsection{Sampling of Mosquitoes}

Thermometers and sling hygrometers were installed in the open areas (outside the house) to monitor the temperature and humidity. Sampling for examination of physical and chemical properties of water was done by taking water samples from several points using bottles. For microbiological examination, the bottle was sterilized in advance. The samples were examined in the laboratory. The result obtained the distribution of abundance, temperature, humidity, water parameters (temperature, TDS/Total Suspended Solids, turbidity, COD/Chemical Oxygen Demand, BOD/Biochemical Oxygen Demand, water pH, coliform), aquatic plant identification, altitude and land utilization. Data processing was done by SPSS 16.

\section{Results and Discussions}

In Sedang Village, Mansonia mosquitoes caught during this period were of 6 species, with Mansonia annulifera, Mansonia uniformis and Mansonia indiana being the most dominant species. While in Muara Sugih village, Mansonia mosquitoes caught during this period were of 5 species with Mansonia uniformis, Mansonia bonneae and Mansonia dives being the most dominant species. The abundance of Mansonia mosquitoes in Sedang Village at most were Mansonia annulifera and Mansonia uniformis. April-June 2017 was the period when the abundance was the highest. In these months the air temperature in Sedang Village was at $27-28^{\circ} \mathrm{C}$. Humidity was at $90 \%$. The most abundant species in the Muara Sugih Village were Mansonia uniformis, Mansonia bonneae and Mansonia dives. April-June period was when the Mansonia spp mosquitoes appeared most. Temperature and humidity in April-June ranged between $28.5-29.5^{\circ} \mathrm{C}$ and $92-96 \%$. 
Table 1 showed that Sedang Village had larger quantity of abundance of biting and resting mosquitoes compared to Muara Sugih. Muara Sugih Village was slightly higher in temperature and humidity than Sedang Village. On the characteristics of water parameters, it was known that Sedang Village water had higher turbidity, higher water temperature, higher $\mathrm{pH}$, lower BOD and COD, lower TDS and TSS as well as higher coliform counts. In terms of altitude, Sedang Village and Muara Sugih were both classified as lowlands.

Table 1. Distribution of Mansonia spp abundance based on environmental characteristics; temperature, humidity and water parameters $(\mathrm{N}=312)$.

\begin{tabular}{|c|c|c|c|}
\hline Variable & Unit & $\begin{array}{c}\text { Sedang } \\
\bar{X}+S D\end{array}$ & $\begin{array}{c}\text { Muara Sugih } \\
\bar{X}+S D\end{array}$ \\
\hline Biting mosquitoes & Mosquitoes & $8,878 \pm 13,618$ & $0,887 \pm 1,861$ \\
\hline Resting mosquitoes & Mosquitoes & $6,509 \pm 9,732$ & $0,548 \pm 1,177$ \\
\hline IF & Mosquitoes & $3,359 \pm 5,095$ & $0,342 \pm 0,853$ \\
\hline OF & Mosquitoes & $4,208 \pm 7,438$ & $0,333 \pm 0,964$ \\
\hline IW & Mosquitoes & $3,009 \pm 4,600$ & $0,234 \pm 0,734$ \\
\hline OW & Mosquitoes & $3,500 \pm 5,726$ & $0,3942 \pm 0,989$ \\
\hline Temperature & ${ }^{\circ} \mathrm{C}$ & $26,83 \pm 3,925$ & $27,75 \pm 3,800$ \\
\hline Humidity & $\%$ & $89,30 \pm 9,501$ & $91,698 \pm 8,728$ \\
\hline Turbidity & $\mathrm{NTU}$ scale & $43,339 \pm 60,11$ & $27,258 \pm 14,31$ \\
\hline Water Temperature & ${ }^{\circ} \mathrm{C}$ & $23,776 \pm 1,03$ & $22,407 \pm 27,43$ \\
\hline Water $\mathrm{pH}$ & & $5,635 \pm 0,445$ & $4,158 \pm 1,039$ \\
\hline BOD & $\mathrm{Mg} / 1$ & $3,459 \pm 4,837$ & $5,109 \pm 6,003$ \\
\hline COD & $\mathrm{Mg} / 1$ & $9,692 \pm 10,826$ & $13,153 \pm 12,043$ \\
\hline TDS & $\mathrm{Mg} / 1$ & $85,092 \pm 131,329$ & $359,638 \pm 769,396$ \\
\hline TSS & $\mathrm{Mg} / 1$ & $26,241 \pm 27,544$ & $433,315 \pm 6,144$ \\
\hline Coliform & $\mathrm{MPN} / 100 \mathrm{ml}$ & $28886,192 \pm 5636,49$ & $1376,164 \pm 4249,04$ \\
\hline Altitude & $\mathrm{MASL}$ & $10 \pm 0,00$ & $12 \pm 0,00$ \\
\hline
\end{tabular}

Abbreviation: IF: Indoor Feeder; OF: Outdoor Feeder; IW Indoor Wall; OW Outdoor Wall; TDS: Total Dissolved Solids, TSS: Total Suspended Solids; COD: Chemical Oxygen Demand, BOD: Biochemical Oxygen Demand.

In previous studies, many species of Mansonia dives, Mansonia bonneae, and Mansonia uniformis found in the crevices of rocks under the grasses [8]. Additionally, many mosquitoes were found resting on crates placed in protected areas in Malaysian settlements. Mansonioidea generally rests much near the ground under the leaves of the grasses. In the Kapuk Village of West Jakarta, Mansonia uniformis were more active outside the home than in the home. Mansonia uniformis began to actively enter the house and bite humans between the hours of 19:00 to 20:00 and between 22:00 to 23:00. Mosquitoes that rest on the walls of the house, were likely more female mosquitoes with the bloody abdomen. Mansonia uniformis were generally outdoors and active at night [10].

There was a discrepancy in mosquito abundance in the study areas. Discrepancy in mosquito abundance indicates differences in availability of breeding places, resting places and climatic factors such as temperature [10]. The only species always present in large numbers in both villages was Mansonia uniformis. Different from Sedang village which had the most abundance of Mansonia annulifera species, in Muara Sugih Village there was 
only small number of variances. In Sedang village with few Mansonia annulata species, the species was not found at all in the village of Muara Sugih. Mansonia indiana was widely available in Sedang Village but very little in Muara Sugih Village. In contrast, Mansonia dives and Mansonia bonneae in the village of Muara Sugih were abundant but were very little in Sedang. According to Rohani et.al., local climatic parameters played an important role in determining the distribution and abundance of vectors because the spread of vectors was limited by the climate tolerance limit of the vectors themselves [11].

The average optimum temperature for mosquitoes is within $25^{\circ} \mathrm{C}-27^{\circ} \mathrm{C}$. Mosquitoes are cold-blooded so that the metabolic processes depend on the temperature of the environment. The increase in temperature has an impact on the acceleration of the mosquito's life cycle from egg to adult mosquito, thus increasing the number of mosquitoes in circulation [12]. In both study area villages, April-June 2017 was the period in which Mansonia spp mosquitoes were most abundant. In these months it was known that the air temperature in Sedang Village was at $27-28^{\circ} \mathrm{C}$. Humidity was at $90 \%$. While in Muara Sugih Village, the temperature and humidity in April-June ranged between $28.5-29.5^{\circ} \mathrm{C}$ and 92-96\%. From the environmental characteristics, Sedang Village had an average temperature of $27.14^{\circ} \mathrm{C} \pm 1.96$ and the average humidity was $91.18 \% \%^{+} 5.35$. The Muara Sugih Village had an average temperature of $25.64^{\circ} \mathrm{C} \pm 1.46$ and an average humidity of $86.92 \% \pm 11.89$. This temperature and humidity corresponded to the temperature required by mosquitoes. Humidity of less than $60 \%$ is one of the factors debilitating mosquitoes' lives so it is not enough for the parasite cycle to grow inside the mosquito body. The mosquito respiratory system also requires moisture content. High humidity affects mosquitoes to find moist and wet spots outdoors as resting places during the day, and facilitates mosquitoes to be more active [12].

The study by Diego and Raquel also stated that Mansonia larvae were found in water conditions with natural water characteristics. There were plants mainly the vegetation of floating aquatic plants, sun-exposed, turbid, stagnant, rain-supplied puddle, containing substrate, as well as wide water surface [13]. Studies conducted by Bashar et al. showed Mansonia larvae found in pools and paddy fields, and water parameters including $\mathrm{pH}$ and temperature played a role in larval abundance [14].

In terms of altitude, Sedang Village and Muara Sugih were both classified as lowlands. However, a study by Anwar et al. stated that filarial vector mosquitoes, Mansonia spp, were scattered throughout the whole gradient of altitude above sea level [15]. Mansonia spp abundance tends to be higher in areas with floating aquatic plants, especially Pistia stratiotes [16]. In line with the findings of this study that in Sedang Village, dominant aquatic plants was Pistia stratiotes $(70.8 \%)$, in contrast to Village Muara Sugih Oryza sativa $(55.1 \%)$.

\section{Conclusion}

Differences in temperature, humidity, water parameters, aquatic plants, and land utilization factors resulted in discrepancy of Mansonia spp abundance. Environmental characteristics that yielded greater abundance of Mansonia spp mosquitoes were the optimal temperature for mosquitoes, high humidity, water parameters of higher turbidity, higher water temperature, higher $\mathrm{pH}$, lower BOD and COD, lower TDS and TSS, and higher coliforms, land utilization of plantations, swamps, and rice fields, with floating aquatic plants, especially Pistia stratiotes. 


\section{Acknowledgments}

The authors would like to deliver gratitude for dr. Evita Yolanda, and the Public Health officers at Banyuasin, Indonesia, for their support.

\section{References}

1. Ndeffo-Mbah M L and Galvani A P. Lancet Infect. Dis 3099 (2016)

2. Murray C J L. Lancet (2015)

3. Ramaiah K D and Ottesen E A. PLoS Negl. Trop. Dis. 8 (2014)

4. Pratiwi R, Anwar C, Salni S, Hermansyah H and Novrikasari N. Diversity of The Mosquitoes as Potential Vector Filariasis in Sungai Rengit Murni Village Banyuasin Regency South Sumatera Province. Prosiding Seminar Nasional Perhimpunan Entomologi Indonesia (2018)

5. World Health Organization Lymphatic Filariasis Practical Entomology Glob, Program. to Elimin, (Lympha, Filariasis ,2013)

6. Banyuasin D kesehatan kabupaten Profil Dinas Kesehatan Kabupaten Banyuasin

7. Oktarina R, Santoso S and Taviv Y. Balaba 3 (2014)

8. Wharton R. Biology of mansonia mosquitoes in relation to the transmission of filariasis in malaya, kuala lumpur, (Institute Medical Research Malaya, 1978)

9. Oktarina R, Yahya Y, Salim M and Pahlevi I. Spirakel 6 (2014)

10. Rajeswari A R Mosquitoe Diversity in Erode District, Tamil Nadu. India World J. Pharm. Res 6 (2017)

11. Rohani A, Zamree I, Wan Mohamad Ali W N, Abdul Hadi A, Asmad M, Lubim D, Mohamed Nor Z and Han Lim L. Adv. Entomol 1 (2013)

12. Kemenkes, Rencana aksi program pengendalian penyakit dan penyehatan lingkungan tahun (2015)

13. Pires D A and Gleiser R M. J. Vector Ecol 35 (2010)

14. Bashar K, Rahman S, Nodi I J and Howlader A J. Pathog. Glob. Health (2016)

15. Anwar C, Ghiffari A, Kuch U and Taviv Y The Abundance of Mosquitoes (Family: Culicidae) Collected in an Altitudinal Gradient In South Sumatra, Indonesia. International Conference on Agricultural, Ecological and Medical Sciences (2015)

16. Ghosh A, Biswas D, Chatterjee S N and Bengal W. J. Aquat. Plant Manag 44 (2006) 